Kathy Acker 
For Heather 


\section{Kathy Acker}

Writing the Impossible

Georgina Colby

EDINBURGH

University Press 
Edinburgh University Press is one of the leading university presses in the UK. We publish academic books and journals in our selected subject areas across the humanities and social sciences, combining cutting-edge scholarship with high editorial and production values to produce academic works of lasting importance. For more information visit our website: edinburghuniversitypress.com

(C) Georgina Colby, 2016

Edinburgh University Press Ltd

The Tun - Holyrood Road, 12(2f) Jackson's Entry,

Edinburgh EH8 8PJ

Typeset in 11/14 Adobe Sabon by IDSUK (DataConnection) Ltd, and printed and bound in Great Britain by CPI Group (UK) Ltd, Croydon CR0 4YY

A CIP record for this book is available from the British Library

ISBN 9780748683505 (hardback)

ISBN 9780748683512 (webready PDF)

ISBN 9780748683529 (epub)

The right of Georgina Colby to be identified as the author of this work has been asserted in accordance with the Copyright, Designs and Patents Act 1988, and the Copyright and Related Rights Regulations 2003 (SI No. 2498). 